\title{
Assessment of Different Quality Characters of Twenty Jackfruit Genotypes under New Alluvial Zone of West Bengal
}

\author{
Avani Pebbuli* and F.K. Bauri \\ Department of Fruits Science, BCKV, Mohanpur 741252, West Bengal, India \\ *Corresponding author
}

\section{A B S T R A C T}

Keywords

Jackfruit, Quality parameters and PCA (Principle component Analysis)

\section{Article Info}

Accepted:

17 November 2018

Available Online:

10 December 2018
An experiment was conducted using twenty different jackfruit genotypes under AICRP on Fruits, B.C.K.V., Mohanpur centre during 2015-2017. Noticeable variations were recorded among the genotypes with respect to biochemical characters of fruit like total soluble solids $\left(16^{\circ}\right.$ Brix to $29.90^{\circ}$ Brix), total sugars $(11.4 \%$ to $50 \%)$, reducing sugars $(2.4 \%$ to $9.5 \%)$, nonreducing sugars $(7.6 \%$ to $42.30 \%), \beta$-carotene content $(12.840 \mathrm{mg} / \mathrm{g}$ to $105.739 \mathrm{mg} / \mathrm{g})$, total titratable acidity $(0.13-0.55 \%)$, acidic acid (2-8 $\mathrm{mg})$, TSS: Acid ratio (45-181), phenol (8.497-34.522 mg GAE/g of dry sample) and soluble protein $(33.862-144.751 \mathrm{mg} / \mathrm{g}$ of dry sample).

\section{Introduction}

Jackfruit (Artocarpus heterophyllus Lam.), is a tetraploid $(4 n=56)$ and is the one of the most significant trees in tropical homegardens and perhaps the most widespread and useful tree in the important genus Artocarpus, of family Moraceae. The jackfruit species reportedly originated in the rainforests of the Western Ghats of India (Chandler, 1958) and in Malaysia (Brown, 1941). Jackfruit is a national fruit of Bangladesh and state fruit of Kerala and Tamilnadu; where it is commonly referred to as "poor man's food" as it is cheap and plentiful during the season. In India, it has wide distribution in Assam, Tripura, Bihar,
Uttar Pradesh, the foothills of the Himalayas and South Indian States of Kerala, Tamil Nadu and Karnataka.

Jackfruit is a multipurpose tree and all parts of the plant are equally important. Fruits are rich in several nutrients. It can act as source of complete nutrition to the consumer. Fruits of jackfruit are compared to avocado and olive in terms of the healthier mix of nutrients for human dietary needs, almost having the exact nutrient equivalent of mother's milk. It is rich in vit-B and $\mathrm{C}$, potassium, calcium, iron, proteins and high level of carbohydrates, affordable and readily available supplement to our staple food. its seeds are rich in proteins 
and can be relished as a nutritious nut. The fruit is also the source of chemical 'Jacalin' useful in preventing colon cancer, AIDS (Priya et al., 2014). Tree is known for its durable anti-termite timber. Jackfruit trees are suitable for growing in wide agro-climatic regions owing to its versatile adaptability, hardy nature, low maintenance cost and high yield. The trees helps in amelioration of soils and prevention of the soil erosion. The leaves and fruit waste provide valuable fodder for cattle, pigs and goats.

Being a cross-pollinated and mostly seed propagated tree, jackfruit has innumerable types or forms in terms of fruit characteristics. The types differ widely among themselves and many types available in India under various local names have originated in this way. However, distinct cultivars are not available. Selection of superior genotypes for the fresh market and the processing industry, as well as for high yield and better quality, would be of great value for commercialization of this underutilized nutritive fruit. Thus, present study was under taken to assess the qualitative variations among twenty genotypes and selection or superior quality fruit genotypes.

\section{Materials and Methods}

A study entitled "Assessment of different quality characters of twenty jackfruit genotypes under new alluvial zones of west Bengal" was conducted at ICAR-AICRP on Fruits, B.C.K.V., Mohanpur centre during 2015-2017. Various quality characters were observed in all the twenty genotypes as per the descriptor developed by Bioversity International (IPGRI).

TSS and ascorbic acid of fruit pulp was measured with the help of A.O.A.C. (1984) methods. Reducing, non reducing and total sugars were also estimated (Ranganna, 1986). titratable acidity content was estimated following the methods of Sadasivam and Manickam (1996). $\beta$-carotene content of lake pulp was estimated using methods of Davies, 1976. Total phenol content of seed and total soluble protein of seed were estimated using Gul et al., 2011 and Lowry et al., (1951) methods respectively.

Principal components were computed from the correlation matrix and genotypic scores obtained for the first component and succeeding components with latent roots greater than unity (Jager et al., 1983).

\section{Results and Discussion}

Variation was noticed with respect to biochemical characters of fruit in all twenty genotypes of jackfruit. The results presented in Table 1 revealed that the TSS content in fruits of jackfruit genotypes differed among genotypes. The total soluble solids (TSS) ranged from $16^{\circ}$ Brix to $26.9^{\circ}$ Brix among the genotypes studied, while highest TSS was observed in genotype G-17 $\left(26.9^{\circ}\right.$ Brix $)$ and the lowest TSS recorded in G-2 (16.0 $0^{\circ}$ Brix). Wangchu et al., (2013) also observed bulb's TSS ranged between $20-28.67^{\circ}$ Brix. similarly Maximum total sugars content was recorded in the genotype G-20 (50\%), while lowest total sugars content was recorded for the genotype in G-7 (11.4 \%). Krishnan et al., (2015) also reported total sugar ranged from 20.84-61.88 per cent. Highest amount of reducing sugars was recorded in the genotype, G-16 (9.5\%), followed by G-20 (7.7\%). Further, lowest amount of reducing sugars was recorded in the genotype, G-19 (2.4\%) and the other genotypes fell in intermediary range. Reddy et al., (2004) also recorded variation in reducing sugars content of pulp. The non- reducing sugars content of pulp ranged from $7.60 \%$ to $42.30 \%$. Even though jack fruit is not a rich source of ascorbic acid, its content ranged from $2.0-8.0 \mathrm{mg} / 100 \mathrm{~g}$ in the present study. The maximum vitamin- $\mathrm{C}$ was recorded in $\mathrm{G}-1$ 
(8.0 $\mathrm{mg})$ and minimum was in G-8 $(2.0 \mathrm{mg})$. Saji et al., (2015) recorded vitamin-C content in different accessions ranged from 4.0 to $12.5 \mathrm{mg} / 100 \mathrm{~g}$. $\beta$-carotenoids varied significantly in all the accessions. Colour of ripe bulbs is a major factor determining organoleptic quality. Total carotenoid content varied from $12.840 \mathrm{mg} / \mathrm{g}$ to $105.739 \mathrm{mg} / \mathrm{g}$. Among the various genotypes the highest $\beta$ carotene content was recorded in G-15 (105.739 mg/g), while lower carotene content was recorded for $\mathrm{G}-13(12.840 \mathrm{mg} / \mathrm{g})$. The total titrable acidity among the genotypes was ranged between 0.13 to $0.55 \%$. The grand mean of total titratable acidity was $0.30 \%$, while highest acidity content was observed in G-18 (0.55\%) and lowest in G-5 (0.13). Analogous observations in accordance to this finding also reported by Bal (2003) with wide diversity among four genotypes of jackfruit acidity from $0.28 \%$ (JFC-4) to $0.34 \%$ (JFS-3). TSS: Acid ratio of pulp varied from 45-181, where the grand mean noted was 89 . The maximum TSS: Acid ratio was recorded in G5 (181) and minimum was in G-8 (45). Chandan (2001) also reported same type of finding and reported varied TSS: Acid ratio content of flesh from 29.69-173.85, highest
TSS: Acid ratio was recorded in T-28 (173.85). Results with regard to total phenol content studied among the genotypes (Table 1) noted varied from 8.497-54.522 mg GAE/gm of dry sample, the maximum content of total phenol content in G-5 $(54.522 \mathrm{mg}$ GAE/gm of dry sample). The lowest content of total phenol content was recorded in G-20 (8.497 mg GAE/gm of dry sample). Soluble protein content in the dry seed powder was observed to be varied from 33.862-144.751 $\mathrm{mg} / \mathrm{g}$ of dry sample. The grand mean recorded was $92.502 \mathrm{mg} / \mathrm{g}$ of dry sample, whereas maximum protein was observed in G-3 (144.751 mg/g of dry sample) and minimum protein content in G-5 $(33.862 \mathrm{mg} / \mathrm{g}$ of dry sample). According to Mitra and Mani (2000) jackfruit types with TSS and total sugars more than $25^{\circ}$ Brix and 20 per cent, respectively were found to be suitable for dessert purpose. Hence the genotypes G-17, G-19 and G-16 can be suggested for table purpose. whereas the genotypes like G-3, G-7 and G-13 having high TSS, protein content and phenol content in seed was recorded which was highly beneficial for industries, street vendors and for home level processing units.

Table.1 Eigen value and variability of fruit quality characters of jackfruit based on principal component analysis

\begin{tabular}{|c|c|c|c|}
\hline COMPONENT & PC1 & $\mathrm{PC} 2$ & PC3 \\
\hline Eigen value & 3.268 & 2.216 & 1.361 \\
\hline$\%$ Variance & 32.681 & 22.157 & 13.611 \\
\hline CHARACTERS & \multicolumn{3}{|c|}{ EIGEN VECTORS } \\
\hline TSS & .740 & .190 & -.496 \\
\hline Acidity & .466 & -.740 & -.149 \\
\hline Total Sugars & .836 & .424 & .221 \\
\hline Reducing Sugars & .643 & .143 & .016 \\
\hline Non- Reducing Sugars & .786 & .436 & .238 \\
\hline Vit-C & -.328 & -.098 & .670 \\
\hline TSS:Acidity & -.195 & .932 & -.152 \\
\hline $\begin{array}{l}\text { Phenol content mg GAE/g of dry seed } \\
\text { powder }\end{array}$ & .580 & -.295 & .430 \\
\hline protein $\mu \mathrm{g} / 100 \mathrm{mg}$ of dry seed powder & .398 & -.227 & .382 \\
\hline$\beta$ - Carotene & .365 & -.475 & -.431 \\
\hline
\end{tabular}


Table.2 Fruit biochemical characters of different selected jackfruit genotypes

\begin{tabular}{|c|c|c|c|c|c|c|c|c|c|c|c|}
\hline \multicolumn{2}{|c|}{ Genotype } & $\begin{array}{c}\text { TSS } \\
\left({ }^{0} \text { Brix }\right)\end{array}$ & $\begin{array}{c}\text { Acidity } \\
(\%)\end{array}$ & $\begin{array}{l}\text { Total } \\
\text { Sugars } \\
(\%)\end{array}$ & $\begin{array}{l}\text { Reducing } \\
\text { Sugars } \\
(\%)\end{array}$ & $\begin{array}{c}\text { Non- } \\
\text { Reducing } \\
\text { Sugars (\%) }\end{array}$ & $\begin{array}{l}\text { Vitamin- } \\
\text { C (mg) }\end{array}$ & $\begin{array}{c}\text { TSS: } \\
\text { Acidity }\end{array}$ & $\begin{array}{l}\text { Phenol (mg } \\
\text { GAE/g of dry } \\
\text { sample) }\end{array}$ & $\begin{array}{l}\text { Soluble protein } \\
\text { (mg/g of dry seed } \\
\text { powder) }\end{array}$ & $\begin{array}{l}\beta \text {-carotene } \\
\text { (mg/g fresh } \\
\text { bulb) }\end{array}$ \\
\hline \multicolumn{2}{|c|}{ G-1 } & 19 & 0.16 & 19.2 & 2.9 & 16.4 & 8 & 119 & 11.033 & 100.127 & 74.991 \\
\hline \multicolumn{2}{|c|}{ G-3 } & 19.3 & 0.32 & 15.6 & 4.2 & 11.5 & 4 & 60 & 23.727 & 144.751 & 82.528 \\
\hline \multicolumn{2}{|c|}{ G-4 } & 20.5 & 0.38 & 25.0 & 5.7 & 19.3 & 6 & 53 & 13.574 & 130.993 & 64.657 \\
\hline \multicolumn{2}{|c|}{ G-5 } & 23.2 & 0.13 & 35.7 & 6.1 & 29.7 & 4 & 181 & 8.497 & 33.862 & 55.721 \\
\hline \multicolumn{2}{|c|}{ G-7 } & 18.2 & 0.32 & 11.4 & 3.8 & 7.6 & 4 & 57 & 24.366 & 50.365 & 77.098 \\
\hline \multicolumn{2}{|c|}{ G-8 } & 24.7 & 0.19 & 20.8 & 3.6 & 17.3 & 2 & 129 & 14.210 & 131.343 & 69.342 \\
\hline \multicolumn{2}{|c|}{ G-9 } & 21 & 0.26 & 17.9 & 3.3 & 14.5 & 4 & 82 & 14.210 & 74.049 & 33.291 \\
\hline \multicolumn{2}{|c|}{ G-10 } & 22.3 & 0.16 & 31.3 & 5.0 & 26.3 & 4 & 139 & 11.671 & 95.243 & 46.567 \\
\hline \multicolumn{2}{|c|}{ G-11 } & 21.6 & 0.26 & 13.9 & 4.1 & 9.8 & 6 & 84 & 12.306 & 46.220 & 86.905 \\
\hline \multicolumn{2}{|c|}{ G-12 } & 21.7 & 0.32 & 17.9 & 4.8 & 13.1 & 6 & 68 & 9.132 & 82.573 & 28.513 \\
\hline \multicolumn{2}{|c|}{ G-13 } & 22.4 & 0.19 & 20.8 & 6.5 & 14.4 & 4 & 117 & 13.575 & 72.493 & 12.840 \\
\hline \multicolumn{2}{|c|}{ G-14 } & 23.3 & 0.26 & 41.7 & 5.7 & 36.0 & 4 & 91 & 17.384 & 74.419 & 20.723 \\
\hline \multicolumn{2}{|c|}{ G-16 } & 24.8 & 0.35 & 35.7 & 9.5 & 26.2 & 4 & 70 & 21.827 & 140.626 & 33.780 \\
\hline \multicolumn{2}{|c|}{ G-17 } & 26.9 & 0.29 & 25.0 & 7.1 & 17.9 & 4 & 93 & 11.671 & 110.013 & 87.177 \\
\hline \multicolumn{2}{|c|}{ G-18 } & 25 & 0.55 & 24.6 & 6 & 18.6 & 4 & 45 & 13.575 & 55.172 & 93.080 \\
\hline \multicolumn{2}{|c|}{ G-19 } & 25.6 & 0.48 & 35.7 & 2.4 & 33.3 & 4 & 53 & 16.114 & 104.428 & 75.518 \\
\hline \multicolumn{2}{|c|}{ G-20 } & 24.4 & 0.32 & 50.0 & 7.7 & 42.3 & 6 & 76 & 34.522 & 123.578 & 80.512 \\
\hline \multicolumn{2}{|c|}{ Grand mean } & 22.1 & 0.3 & 25.4 & 5.1 & 20.3 & 4.8 & 89.0 & 15.415 & 92.502 & 64.695 \\
\hline \multirow{2}{*}{\begin{tabular}{l}
$\mathbb{8}$ \\
\multirow{\infty}{*}{} \\
$\approx$
\end{tabular}} & $\operatorname{Max}$ & $\begin{array}{c}26.9 \\
(\mathrm{G}-17)\end{array}$ & $\begin{array}{c}0.55(\mathrm{G}- \\
18)\end{array}$ & $50(\mathrm{G}-20)$ & $\begin{array}{c}9.5(\mathrm{G}- \\
16)\end{array}$ & $42.3(\mathrm{G}-20)$ & $8(\mathrm{G}-1)$ & $181(\mathrm{G}-5)$ & $34.522(\mathrm{G}-5)$ & $144.751(\mathrm{G}-3)$ & $105.739(\mathrm{G}-15)$ \\
\hline & Min & $\begin{array}{c}16(\mathrm{G}- \\
2)\end{array}$ & $0.13(\mathrm{G}-5)$ & $\begin{array}{c}11.4(\mathrm{G}- \\
7)\end{array}$ & $\begin{array}{c}2.4 \text { (G- } \\
19)\end{array}$ & $7.6(\mathrm{G}-7)$ & $2(\mathrm{G}-8)$ & 45 (G-18) & $8.497(\mathrm{G}-20)$ & $33.862(\mathrm{G}-5)$ & $12.840(\mathrm{G}-13)$ \\
\hline
\end{tabular}


The PCA for quality parameters has been depicted in Table 2. Among the three principle components the first and second principle component axes had eigen value $>2$ and the third principle component had eigen value $>0.5$. PCA of quality traits found that, the first principal component accounted 32.68 $\%$ to the total variability, where TSS, Total sugars and Non-reducing sugars were highly positively loaded on the component. The second principal component accounted 22.16 $\%$ to the total variability. The variables contributing most positively were TSS, Total sugars and Non-reducing sugars. The third component accounted $13.61 \%$ to the variance, in which six characters were contributed positively. Thus, the prominent characters coming together in different principal components and contributing towards explaining the variability and have the tendency to remain together. This may be kept into consideration during utilization of these characters in selecting superior genotypes.

\section{References}

AOAC. 1984. (Official Method of Analysis). $14^{\text {th }}$ Edition, Association of Official Agriculturist Chemist. Washington D.C.

Brown, W.H. 1941. Useful Plants of the Philippines. Dept. Agric. Natl. Res. Tech. Bull. Manila: Bureau of Printing, 1:10.

Chandan, S.M. 2001. Studies on genetic resources of jackfruit (Artocarpus heterophyllus Lamk.) in West Bengal. Ph.D. Thesis. Bidhan Chandra Krishi Viswavidyalaya, Mohanpur, West Bengal.

Chandler, W.H. 1958. Evergreen Orchards. $2^{\text {nd }}$ Ed. Henry Kimpton, London.

Davies, H. 1976. IN: Goodwin, T.W. ed. Chemistry and Biochemistry o PLant pingments. London: Academic press, pp. 38.

Gul, M.Z., Bhakshu, L.M., Ahmad, F., Kondapi, A.K., Qureshi, I.A. and Ghazi, I.A. 2011. Evaluation of Abelmoschus moschatus extracts for antioxidant, free radical scavenging, antimicrobial and antiproliferative activities using in vitro assays. BMC complement Altern Med., 11:64.

Jager, M. I., Jarethojones, D. and Griffith, E. (1983). Component of partial resistance of wheat seedlings to Septoria nodorum. Euphytica, 32: 575-584.

Krishnan, A.G., Jayalekshmi, G., Joseph, E. and Sabu, T.S. 2015. Assessment of physico-chemical properties of jackfruit collections from Kuttanad region of Kerala. Asian J. Hort., 10(2): 262-66.

Lowry, O.H., Rosebrough, N.J. and Land Randall, R.J.F.A. 1951. Protein measurement with the FolinPhenol reagents. J. Biol. Chem., 48:17-25.

Mitra, S.K. and Mani, D. 2000. Conservation and utilization of genetic resources in Jackfruit (Artocarpus heterophyllus Lam.): a potential underutilized fruits. Acta Hortic., 523: 229-32.

Priya, D.S., Sunetra, T., Mathala, J.G., Thangam, M. and Singh, N.P. 2014. A guide to jackfruit- cultivation and value addition. Technical bulletin No. 41, ICAR (RC), Goa. pp. 2.

Reddy, B.M.C, Prakash, P., Kumar, S.S. and Govindaraju, R. 2004. Studies on physico-chemical characteristics of jackfruit clones of South Karnataka. Karnataka J. Agric. Sci., 17(2): 27982.

Sadasivam, S. and Manickam, A. 1996. Biochemical methods. 2nd edition, New Age International (p) Ltd. Publisher, New Delhi, pp.179-86.

Saji, G., Meagle, J.P., Sheela, K.B., Sruthi, C.V. and Linju, L. 2015. Variability in 
fruiting season and quality attributes of Jackfruit (Artocarpus heterophyllus Lam.) accessions of Kerala. Nat. academy Agric. sci., 33(2): 1249-55.

Wangchu, L. 2005. Selection of superior jackfruit genotypes and their identification through electrophoretic banding patterns of isozymes. Ph.D. Thesis. Bidhan Chandra Krishi Viswavidyalaya, Mohanpur, West Bengal.

\section{How to cite this article:}

Avani Pebbuli and Bauri, F.K. 2018. Assessment of Different Quality Characters of Twenty Jackfruit Genotypes under New Alluvial Zone of West Bengal Int.J.Curr.Microbiol.App.Sci. 7(12): 2621-2626. doi: https://doi.org/10.20546/ijcmas.2018.712.297 